\title{
Photosynthetic Pigments and Photochemical Efficiency in Soursop under Saline Water Irrigation and Nitrogen Sources
}

\author{
Evandro M. da Silva ${ }^{1}$, Geovani S. de Lima ${ }^{1}$, Hans R. Gheyi ${ }^{1}$, Reginaldo G. Nobre ${ }^{2}$, Francisco Vanies da Silva Sá ${ }^{1}$, \\ Leandro de Pádua Souza ${ }^{1}$, Lauriane Almeida dos Anjos Soares ${ }^{2} \&$ Pedro Dantas Fernandes ${ }^{1}$ \\ ${ }^{1}$ Academic Unit of Agricultural Engineering, Federal University of Campina Grande, Campina Grande, Brazil \\ ${ }^{2}$ Center of Science and Agri-Food Technology, Federal University of Campina Grande, Pombal, Brazil \\ Correspondence: Evandro M. da Silva, Academic Unit of Agricultural Engineering, Federal University of \\ Campina Grande, Paraíba, Brazil. Tel: 55-083-98116-1622. E-mail: evandroagroman@hotmail.com
}

Received: October 1, 2017

Accepted: November 3, 2017

Online Published: November 15, 2017

doi:10.5539/jas.v9n12p325

URL: https://doi.org/10.5539/jas.v9n12p325

\begin{abstract}
The Studies have shown that nitrogen fertilization can mitigate the effects of saline stress on plants, however, the efficiency may vary according to the source of nitrogen used, specifically on the photosynthetic activity. In this context, the objective of this work was to evaluate the effect of different nitrogen sources on photosynthetic pigments and photochemical efficiency in soursop plants irrigated with distinct salinities. A randomized complete block design was used in a $4 \times 4$ factorial scheme, with the treatments corresponding to four levels of irrigation water salinity - $\mathrm{ECw}\left(0.5,1.5,2.5\right.$ and $\left.3.5 \mathrm{dS} \mathrm{m}^{-1}\right)$ and four sources of nitrogen (urea, ammonium sulfate, calcium nitrate and potassium nitrate), with three replications. The irrigation with saline water from 0.5 $\mathrm{dS} \mathrm{m} \mathrm{m}^{-1}$ inhibits the concentration of photosynthetic pigments and promotes damages in the photochemical efficiency of photosynthesis at 110 days after transplanting. The different sources of nitrogen do not cause changes in the levels of photosynthetic pigments, however, the fertilization with potassium nitrate mitigates the effect of saline stress on the photochemical efficiency, mainly in the water salinity of $3.5 \mathrm{dS} \mathrm{m}^{-1}$.
\end{abstract}

Keywords: Annona muricata L., nitrogen fertilization, photosynthesis, salinity

\section{Introduction}

Soursop (Annona muricata L.) is one of the most cultivated species of the Annonaceae family in regions of tropical climate, where it adapts well to the edaphoclimatic conditions (Cavalcanti Junior et al., 2010), and the increasing demand for the pulp its fruit in internal and external markets has stimulated its exploitation by fruit growers (Rozane \& Natale, 2014).

In semi-arid regions, crop management depends on irrigation, in many cases with high-salinity water, which consists in the greatest limitation to the establishment of this fruit crop, compromising its nutritional balance, physiology, growth and production (Távora et al., 2004).

Evaluation of photosynthetic pigments and fluorescence parameters allows to assess the effect of various types of stress on photosynthesis, including salinity, which reduces photosynthetic rate and electron transport, disorders driven by light through the emission of heat or fluorescence (Azevedo Neto et al., 2011; Baker, 2008), which are related to chlorophyll degradation by salt stress (Munns \& Tester, 2008) and reduction in the absorption and use of light energy through photosystem II, during the photochemical reactions of photosynthesis (Baker, 2008).

Nitrogen $(\mathrm{N})$ has structural function in the plant, constituting amino acids, $\mathrm{N}$ bases, many enzymes and energy-transfer materials such as chlorophyll and proteins of the electron transport chain in chloroplasts (Taiz \& Zeiger, 2013). In soursop, $\mathrm{N}$ deficiency directly affects physiology, with gradual loss of green color and premature fall of leaves, which often negatively affect crop growth and development (São José et al., 2014).

Andrade Júnior et al. (2011) report that the increase in the dose of certain $\mathrm{N}$ fertilizers applied in a salinity-sensitive crop may lead to increment in its tolerance to salinity, with consequences in plant nutrition and physiology. However, special attention should be paid to the choice of the $\mathrm{N}$ source, especially when the use of saline water is inevitable, because most $\mathrm{N}$ sources available in the market are salts, which may increase soil salinity (Oliveira et al., 2010). 
Ammonium sulfate and urea are the most used $\mathrm{N}$ sources in the Brazilian agriculture, possibly because of their lower cost and greater availability in the market (Binotti et al., 2010). However, there are reports that the fertilization with calcium nitrate and potassium nitrate reduces salt stress effects on plants (Andrade Júnior et al., 2011; Fernandes et al., 2010).

Hence, this study aimed to evaluate the effect of different $\mathrm{N}$ sources on the photosynthetic pigments and photochemical efficiency in soursop plants irrigated with solutions of different saline levels.

\section{Materials and Methods}

\subsection{Experiment Localization and Treatments}

The experiment was carried out from August to December 2016 in a greenhouse, arc model (width $=12 \mathrm{~m}$, length $=25 \mathrm{~m}$ and right-foot height $=4 \mathrm{~m}$ ), covered with a 100 micron plastic film, having on the sides a shading screen of 50\% luminosity, at the Center of Technology and Natural Resources (CTRN) of the Federal University of Campina Grande (UFCG), in Campina Grande-PB, Brazil ( $7^{\circ} 12^{\prime} 88^{\prime \prime} \mathrm{S}, 35^{\circ} 54^{\prime} 40^{\prime \prime} \mathrm{O} ; 532 \mathrm{~m}$ ). According to the climatic classification of Köeppen, adapted to Brazil (Coelho \& Soncin, 1982), the climate of the region is of type Csa, which represents mesothermal climate, subhumid; average annual precipitation of $802.7 \mathrm{~mm}$ and average temperature of $23.5^{\circ} \mathrm{C}$ (IMMET, 2017).

Were studied 16 treatments arranged in a $4 \times 4$ factorial scheme, corresponding to four levels of irrigation water salinity - ECw $\left(0.5 ; 1.5 ; 2.5\right.$ and $\left.3.5 \mathrm{dS} \mathrm{m}^{-1}\right)$ and four $\mathrm{N}$ sources (urea, ammonium sulfate - AS, calcium nitrate $\mathrm{CN}$ and potassium nitrate $-\mathrm{KN}$ ), distributed in randomized blocks, with three replicates, and the experimental unit consisted in a pot with one plant, totalizing 48 plots in the experiment.

The $\mathrm{N}$ dose applied through the different fertilizers, as well as phosphate and potassium fertilizations, were based on the recommendations for pot experiments (Novais et al., 1991), using 100, 300 and $150 \mathrm{mg} \mathrm{kg}^{-1} \mathrm{of} \mathrm{N}^{\mathrm{N}}$, $\mathrm{P}_{2} \mathrm{O}_{5}$ and $\mathrm{K}_{2} \mathrm{O}$, respectively. Phosphate fertilization was performed by incorporating single superphosphate to the soil in the planting hole, whereas $\mathrm{N}$ and $\mathrm{K}$ (potassium chloride) fertilizations were split into six applications in equal parts, by the dilution of each fertilizer in $150 \mathrm{ml}$ of rainwater, manually applied in soil surface, starting 20 days after transplantation (DAT), followed by applications every 10 days.

Saline solutions with ECw of 0.5 and $1.5 \mathrm{dS} \mathrm{m}^{-1}$ were prepared by mixing rainwater $\left(0.02 \mathrm{dS} \mathrm{m}^{-1}\right)$ with water from the public supply system $\left(1.7 \mathrm{dS} \mathrm{m} \mathrm{m}^{-1}\right)$, whereas solutions with ECw of 2.5 and $3.5 \mathrm{dS} \mathrm{m}^{-1}$ were prepared through the addition of commercial iodine-free $\mathrm{NaCl}$ salts.

\subsection{Plant Material and Management of the Experiment}

The soursop variety 'Nordestina' was used in the experiment and its seedlings were obtained by sowing in 288 $\mathrm{cm}^{3}$ plastic tubes containing substrate composed of soil and humus (2:1 proportion). The seedlings were transplanted 86 days after sowing, when they had four true leaves, fully expanded, to $22 \mathrm{dm}^{3}$ pots containing 20 $\mathrm{kg}$ of soil, whose physical and chemical characteristics (Table 1) were analyzed according to Claessen (1997).

Table 1. Physical and chemical characteristics of the Fluvisol soil used in the experiment

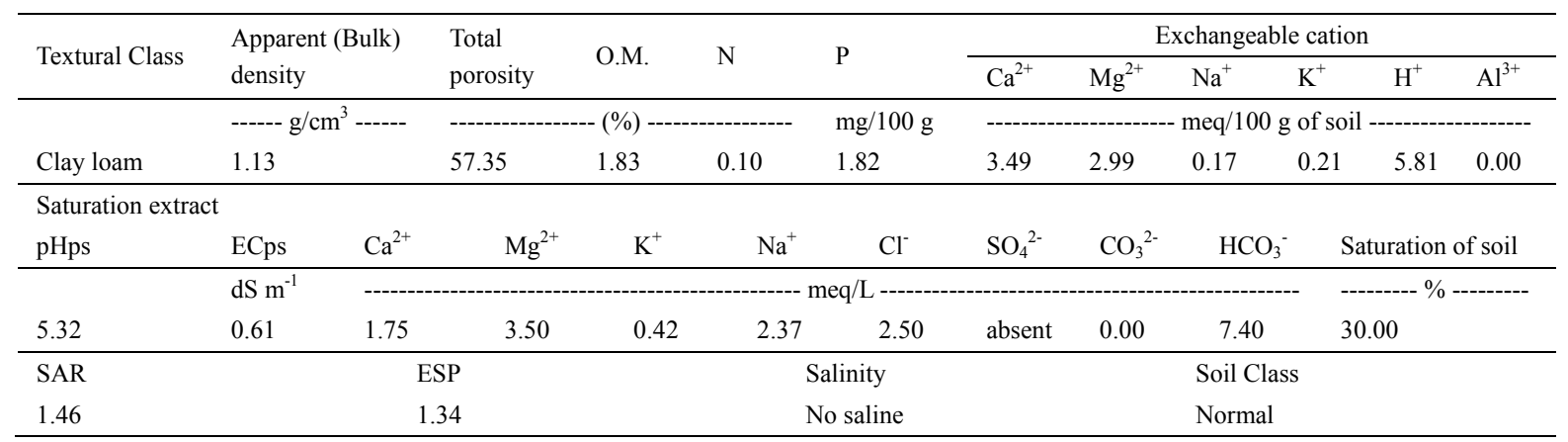

Note. O.M. $=$ Organic matter; $\mathrm{pHps}=\mathrm{pH}$ of saturated paste of the substrate, ECes $=$ Electrical conductivity of the saturation extract of the substrate at $25^{\circ} \mathrm{C}$; SAR $=$ Sodium adsorption ratio; ESP $=$ Exchangeable sodium percentage; $\mathrm{Ca}^{2+}$ and $\mathrm{Mg}^{2+}$ extracted with $\mathrm{KCl} 1 \mathrm{M}$ at $\mathrm{pH}$ 7.0; $\mathrm{P}, \mathrm{Na}^{+}$and $\mathrm{K}^{+}$extracted with extractor Mehlich-1; O.M.: determined by wet digestion Walkley-Black method. 
The planting pots had a layer of crushed stone $\left(\mathrm{n}^{\circ} 0\right)$ at the bottom, involved by a nonwoven geotextile (Bidim OP 30$)$, connected to a drain and a hose (20 $\mathrm{mm}$ diameter), which allow to monitor the drained volume and estimate water consumption by the crop.

Saline solutions began to be applied at 10 DAT and the different treatments were irrigated considering the estimate of crop water consumption, based on the drainage lysimetry principle (Bernardo et al., 2006), using as lysimeters, the pots of the experimental plots. At 60 DAT, a leaching fraction of 0.15 was applied based on the volume applied in this period, in order to minimize the accumulation of salts in the soil.

\subsection{Variables Measured}

Effects of treatments on plant physiology were evaluated at 110 DAT, based on the photosynthetic pigments: chlorophyll $a(\mathrm{CHL} a)$, chlorophyll $b$ (CHLb), total chlorophyll (CHLtotal), carotenoids (CAR), chlorophyll $a$ /chlorophyll $b$ ratio (CHL $a / \mathrm{CHL} b$ ) and total chlorophyll/carotenoids ratio (CHLtotal/CAR), besides chlorophyll fluorescence, including: maximum fluorescence $(\mathrm{Fm})$, variable fluorescence $(\mathrm{Fv})$, quantum efficiency of photosystem II (Fv/Fm) and basal quantum yield of photosystem II (Fo/Fm).

Photosynthetic pigments were determined in the fifth fully expanded leaf, from the apical bud to the base of the plant. A cork borer was used to collect a plant tissue disc from the middle third of the leaf blade, with area of $3.14 \mathrm{~cm}^{2}$. After that, the material was chopped and immersed in $6 \mathrm{~cm}^{3}$ of acetone at $80 \%$ in $10 \mathrm{~cm}^{3}$ glass containers, where the samples remained in full darkness for 48 hours in a refrigerator at temperature of $8{ }^{\circ} \mathrm{C}$ to extract the pigments from the supernatant. Subsequently, contents of chlorophyll a, chlorophyll b, total chlorophyll and carotenoids were quantified through spectrophotometry with absorbance (A) readings respectively at the wavelengths of 663,646 and $470 \mathrm{~nm}$, using $80 \%$ acetone as blank, according to Equations 1, 2, 3 and 4, following the methodology of Lichtenthäler (1987):

$$
\begin{gathered}
C H L a=12.21 \times A_{663}-2.81 \times A_{646} \\
C H L b=20.13 \times A_{646}-5.03 \times A_{663} \\
\text { CHLtotal }=17.3 \times A_{646}+7.18 \times A_{663} \\
C A R=(1000 \times A 470-1.82 \times C L a-85.02 \times C L b) / 198
\end{gathered}
$$

The data were obtained in $\mathrm{mg} \mathrm{L}^{-1}$ and, based on the leaf disc area $\left(3.14 \mathrm{~cm}^{2}\right)$ and on extract dilution in $6 \mathrm{~cm}^{3}(6$ $\mathrm{mL})$ of $80 \%$ acetone, CHL $a, \mathrm{CHL} b$ and CAR contents were transformed to units of mass per $\mathrm{m}^{2}\left(\mathrm{~g} \mathrm{~m}^{-2}\right)$.

Photochemical efficiency was measured through chlorophyll a fluorescence parameters, using the Handy PEA device (Hansatech), by attaching leaf clips to the third fully expanded leaf, from the apex to the base of the plant, which remained for 30 minutes to dark adapt the leaves before the readings. Basal quantum yield of photosystem II (Fo/Fm) was established by the ratio between Fo and Fm (Rohácek, 2002).

\subsection{Statistical Analysis}

The obtained data were subjected to analysis of variance by $\mathrm{F}$ test at 0.05 and 0.01 probability levels. In cases of significance, regression analysis was used for the factor saline levels and means comparison test (Tukey) for $\mathrm{N}$ sources, using the statistical software SISVAR/UFLA (Ferreira, 2011). The regression model was selected considering the best fit based on the coefficient of determination $\left(\mathrm{R}^{2}\right)$.

\section{Results and Discussion}

Irrigation water salinity had significant effect $(\mathrm{p}<0.01)$ on the contents of CHLa, CHLb, CHLtotal, CAR, $\mathrm{CHLa} / \mathrm{CHLb}$ and CHLtotal/CAR (Table 2). However, there was no significance of $\mathrm{N}$ sources or significant interaction $(p>0.05)$ between the factors irrigation water salinity and $\mathrm{N}$ sources for the studied variables.

Increment in irrigation water salinity negatively affected the contents of photosynthetic pigments in soursop leaves, leading to linear reductions of 15.72, 10.40, 14.44, 9.00, 7.88 and 7.84\% in CHL $a$, CHL $b$, CHLtotal, $\mathrm{CAR}, \mathrm{CHL} a / \mathrm{CHL} b$ and $\mathrm{CHL}$ total/CAR (Figures $1 \mathrm{~A}, 1 \mathrm{~B}, 1 \mathrm{C}, 1 \mathrm{D}, 1 \mathrm{E}$ and $1 \mathrm{~F}$ ), respectively, per unit increase in ECw. 
Table 2. Summary of the analysis of variance for chlorophyll a (CHLa), chlorophyll b (CHLb), total chlorophyll (CHLtotal), carotenoids (CAR), chlorophyll a/chlorophyll $\mathrm{b}$ ratio (CHLa/CHLb) and total chlorophyll/carotenoids ratio (CHLtotal/CAR) of in soursop plants, 'Nordestina' variety, irrigated with solutions of different saline levels and fertilized with different nitrogen sources at 110 days after transplantation

\begin{tabular}{|c|c|c|c|c|c|c|c|}
\hline \multirow{2}{*}{ SV } & \multicolumn{7}{|c|}{ Mean Square } \\
\hline & FD & CHLa & CHL $b$ & CLHtotal & CAR & $\mathrm{CHL} a / \mathrm{CHL} b$ & CHLtotal/CAR \\
\hline Salinity (S) & 3 & $0.04261 * *$ & $0.00192 * *$ & $0.06256^{* *}$ & $0.00099 * *$ & $1.28127 * *$ & $3.33370 * *$ \\
\hline Nitrogen Sources (NS) & 3 & $0.00082^{\mathrm{ns}}$ & $0.00013^{\mathrm{ns}}$ & $0.00158^{\mathrm{ns}}$ & $0.00006^{\mathrm{ns}}$ & $0.01830^{\mathrm{ns}}$ & $0.18169^{\mathrm{ns}}$ \\
\hline Interaction $\mathrm{S} * \mathrm{NS}$ & 9 & $0.00039^{\mathrm{ns}}$ & $0.00006^{\mathrm{ns}}$ & $0.00064^{\mathrm{ns}}$ & $0.00004^{\mathrm{ns}}$ & $0.04980^{\mathrm{ns}}$ & $0.35588^{\mathrm{ns}}$ \\
\hline Blocks & 3 & $0.00023^{\mathrm{ns}}$ & $0.00001^{\mathrm{ns}}$ & $0.00021^{\mathrm{ns}}$ & $0.00013^{\mathrm{ns}}$ & $0.08583^{\mathrm{ns}}$ & $0.63447^{\mathrm{ns}}$ \\
\hline Residue & 30 & 0.001184 & 0.000092 & 0.001881 & 0.000040 & 0.034421 & 0.206261 \\
\hline $\mathrm{CV}(\%)$ & - & 15,38 & 12,32 & 14,38 & 9,60 & 6,55 & 10,07 \\
\hline
\end{tabular}

Note. $\mathrm{ns}$, non-significant; $* *$ significant at $\mathrm{p} \leq 0.01 ; \mathrm{SV}=$ Sources of variation; $\mathrm{FD}=$ Freedom degree; $\mathrm{CV}=$ coefficient of variation.
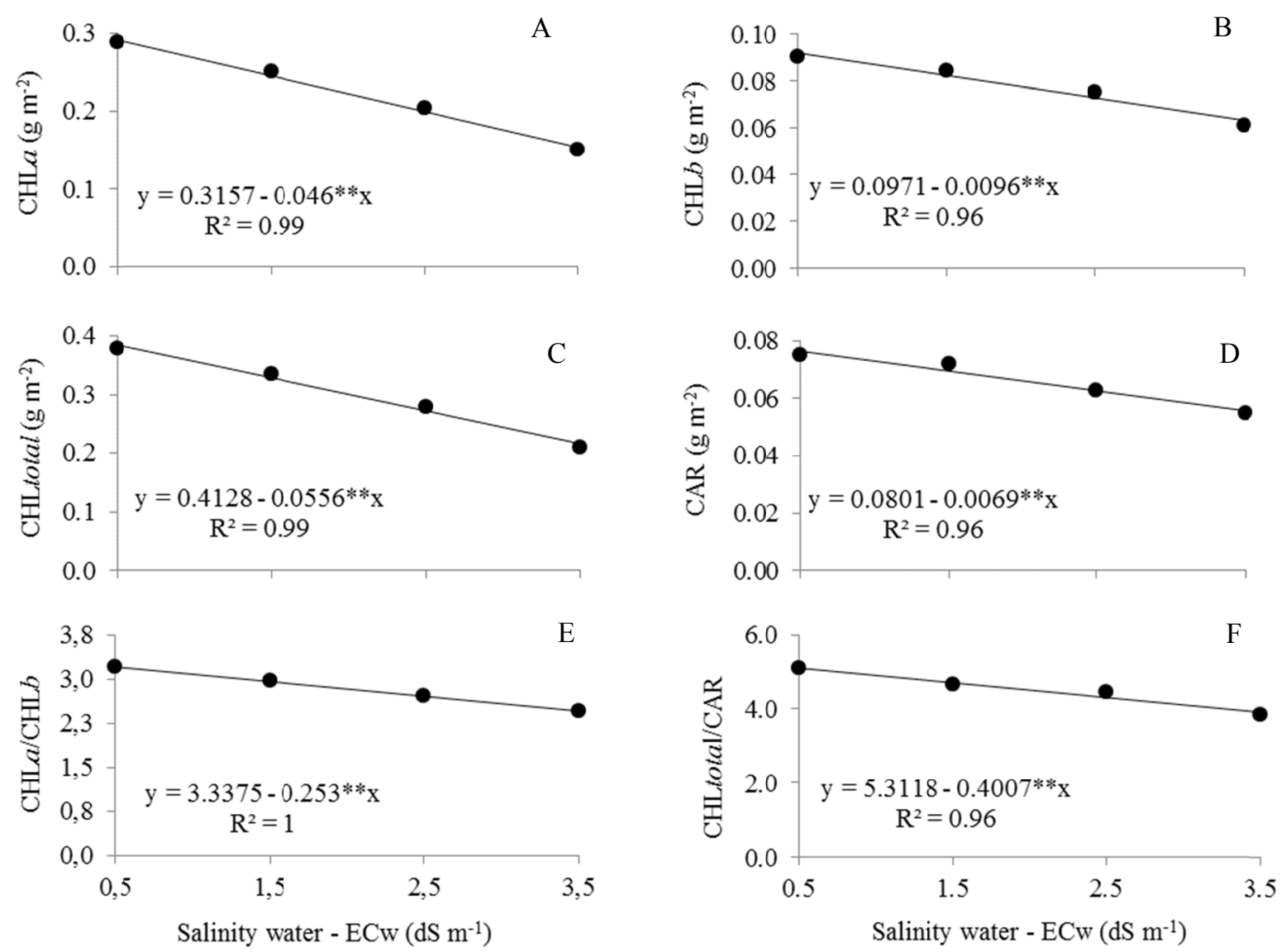

Figure 1. Contents of chlorophyll $a-\mathrm{CHL} a$ (A), chlorophyll $b-\mathrm{CHL} b$ (B), total chlorophyll - CHLtotal (C), carotenoids - CAR (D), chlorophyll $a$ /chlorophyll $b$ ratio - CHL $a / \mathrm{CHL} b$ (E) and total chlorophyll/carotenoids ratio - CHLtotal/CAR (F), in soursop plants, 'Nordestina' variety, as a function of irrigation water salinity at 110 days after transplantation

Note. ${ }^{* *}=$ significant at 0.01 probability levels $(\mathrm{p} \leq 0.01)$.

Reduction in chlorophyll contents under saline conditions may have occurred due to the inhibition in the synthesis of 5-aminolevulinic acid, a chlorophyll precursor molecule (Sacramento et al., 2014; Taiz \& Zeiger, 2013), or to the increase in the activity of the enzyme chlorophyllase, which degrades the molecules of these photosynthesizing pigments (Freire et al., 2013). Thus, salt stress induces degradation of $\beta$-carotene and 
reduction in zeaxanthin formation, structural pigments of the carotenoids, possibly causing decrease in CAR content (Freire et al., 2013; Munns \& Tester, 2008).

Under these conditions, light harvesting efficiency may be reduced because these pigments capture energy at different wavelengths and transfer it to the reaction center, which effectively acts in the photochemical reactions of photosynthesis (Freire et al., 2013). In addition, plant vulnerability to oxidative stress increases, because carotenoids also act as antioxidant agents, protecting membrane lipids of reactive oxygen species in plants exposed to salinity (Falk \& Munné-Bosch, 2010).

Deleterious effect of salt stress on the contents of CHL $a$, CHL $b$, CHLtotal and CAR at ECw levels from 0.5 to $4.5 \mathrm{dS} \mathrm{m}^{-1}$ have been observed in passion fruit (Cavalcante et al., 2011; Freire et al., 2013) and tomato (Tatagiba et al., 2014).

According to the analysis of variance summary (Table 3$)$, there was significant interaction $(p<0.05)$ between the factors irrigation water salinity and $\mathrm{N}$ sources for $\mathrm{Fm}, \mathrm{Fv}, \mathrm{Fv} / \mathrm{Fm}$ and $\mathrm{Fo} / \mathrm{Fm}$.

Table 3. Summary of the analysis of variance analysis of variance for maximum fluorescence (Fm), variable fluorescence (Fv), quantum efficiency of photosystem II (Fv/Fm) and basal quantum yield of photosystem II (Fo/Fm) in soursop plants, 'Nordestina' variety, irrigated with solutions of different saline levels and fertilized with different nitrogen sources at 110 days after transplantation

\begin{tabular}{llllll}
\hline \multirow{2}{*}{ SV } & \multicolumn{5}{c}{ Mean Square } \\
\cline { 2 - 6 } & FD & Fm & Fv & Fv/Fm & Fo/Fm \\
\hline Salinity (S) & 3 & $34979.139^{* *}$ & $28678.611^{* *}$ & $0.004480^{* *}$ & $0.005622^{* *}$ \\
Nitrogen Sources (NS) & 3 & $10884.528^{* *}$ & $5878.778^{* *}$ & $0.001424^{* *}$ & $0.001672^{* *}$ \\
Interaction S*NS & 9 & $5119.287^{*}$ & $3513.167^{*}$ & $0.000504^{*}$ & $0.000510^{*}$ \\
Blocks & 2 & $6496.271^{\mathrm{ns}}$ & $2000.146^{\mathrm{ns}}$ & $0.000290^{\mathrm{ns}}$ & $0.000581 \mathrm{~ns}$ \\
Residue & 30 & 2140.160 & 1328.057 & 0.000227 & 0.000230 \\
CV $(\%)$ & & 6.55 & $7.47^{*}$ & 2.19 & 4.85 \\
\hline
\end{tabular}

Note. ns, non-significant; $*$, ** significant at $\mathrm{p} \leq 0.05$ and $\mathrm{p} \leq 0.01 ; \mathrm{SV}=$ Sources of variation; $\mathrm{FD}=$ Freedom degree; $\mathrm{CV}=$ coefficient of variation.

In the follow-up analysis of water salinity levels for each $\mathrm{N}$ source (Figure 2A), Fm linearly decreased by 5.32 and $5.61 \%$ per unit increase in ECw in plants fertilized with urea and ammonium sulfate (AS), respectively. For plants fertilized with calcium nitrate $(\mathrm{CN}), \mathrm{Fm}$ data fitted best to the quadratic model, with maximum value (772.1 electrons quantum ${ }^{-1}$ ) obtained at $\mathrm{ECW}$ of $1.2 \mathrm{dS} \mathrm{m}^{-1}$. In plants fertilized with potassium nitrate (KN), the Fm of chlorophyll a was not affected by the increment in irrigation water salinity, showing mean value of 746.5 electrons quantum ${ }^{-1}$.

According to the follow-up analysis of $\mathrm{N}$ sources for each level of irrigation water salinity (Figure 2B), significant difference was found in Fm between the different sources only in plants irrigated using solutions with higher saline levels $\left(2.5\right.$ and $\left.3.5 \mathrm{dS} \mathrm{m}^{-1}\right)$. For the irrigation with ECw of $2.5 \mathrm{dS} \mathrm{m}^{-1}$, highest Fm values $(750$ and 740 electrons quantum $\left.{ }^{-1}\right)$ were caused by the fertilization with calcium nitrate $(\mathrm{CN})$ and potassium nitrate $(\mathrm{KN})$, whereas plants subjected to $\mathrm{ECW}$ of $3.5 \mathrm{dS} \mathrm{m}^{-1}$ showed maximum $\mathrm{Fm}\left(709.7\right.$ electrons quantum $\left.{ }^{-1}\right)$ under $\mathrm{KN}$ fertilization. 

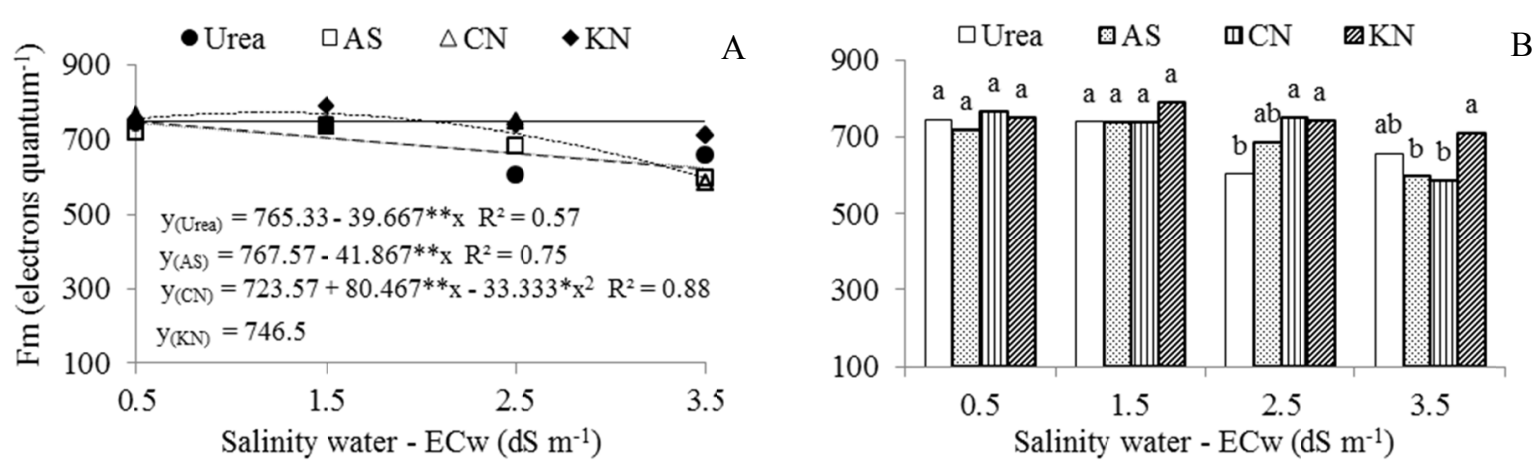

Figure 2. Follow-up analysis of irrigation water salinity levels $-\mathrm{ECw}$ for each nitrogen source (Urea, ammonium sulfate $-\mathrm{AS}$, calcium nitrate $-\mathrm{CN}$ and potassium nitrate $-\mathrm{KN}$ ) (A) and follow-up analysis of nitrogen sources for each level of irrigation water salinity (B) for maximum fluorescence - Fm of chlorophyll $a$ in soursop plants, 'Nordestina' variety, at 110 days after transplantation

Note. $* *, *=$ significant at 0.01 and 0.05 probability levels $(\mathrm{p} \leq 0.01$ and $\mathrm{p} \leq 0.01$ ). Averages not followed by same letter in salinity water level $(\mathrm{smd}=51.61)$ are different among them by Tukey's multiple range test at $5 \%$; smd =significant minimum difference.

Reductions in Fm indicate deficiency in quinone A (QA) photoreduction, which may lead to inactivation of photosystem II and directly affect the electron flow between photosystems I and II in the thylakoid membrane. This phenomenon may occur through the intensification of salt stress, as observed in tomato (Tatagiba et al., 2014) and citrus hybrids (Silva et al., 2014).

Reductions in Fm (Figure 2A) due to increase of salinity occurred in the fertilization with ammoniacal sources (urea and AS), which may have incremented salt stress, because of their high salinity index (75 and 69\%, respectively), or even promoted acidity in the substrate, since the ammoniacal $\mathrm{N}$ supplied by these $\mathrm{N}$ sources, after being absorbed by the root or undergoing biological oxidation in the nitrification process, leads to soil acidification (Borges \& Silva, 2011).

The results found in plants fertilized with $\mathrm{CN}$ and $\mathrm{KN}$ suggest that the effect of salt stress on Fm was mitigated, possibly because these fertilizers promote increments in $\mathrm{K} / \mathrm{Na}$ and $\mathrm{Ca} / \mathrm{Na}$ ratios and increase $\mathrm{NO}_{3}{ }^{-}$absorption, resulting in minimization of the toxic effect of $\mathrm{Na}^{+}$and $\mathrm{Cl}^{-}$, and promote nutritional balance in the plants (Andrade Júnior et al., 2011; Blanco et al., 2008; Fernandes et al., 2010).

Távora et al. (2004) observed in soursop seedlings that the increment of salinity significantly increases $\mathrm{Na}$ and $\mathrm{Cl}$ contents in all plant parts, with subsequent reductions in $\mathrm{Ca}$ and $\mathrm{K}$ contents. Thus, these authors suggest that, under such conditions, salt stress in intensified, which may directly affect physiological parameters such as chlorophyll a fluorescence.

Fv data (Figures 3A and 3B) showed similar behavior to Fm data. According to Figure 3A, Fv showed linear reductions of 6.63 and $7.07 \%$ per unit increase in $\mathrm{ECw}$ in plants fertilized with urea and ammonium sulfate (AS), respectively. In plants receiving $\mathrm{CN}, \mathrm{Fv}$ data fitted best to a quadratic model, with highest value (541.07 electrons quantum ${ }^{-1}$ ) estimated at $\mathrm{ECw}$ of $0.9 \mathrm{dS} \mathrm{m}^{-1}$, whereas $\mathrm{Fv}$ values did not differ with the increase of $\mathrm{ECw}$ in plants fertilized with $\mathrm{KN}$.

The follow-up analysis of $\mathrm{N}$ sources for each level of irrigation water salinity demonstrated that $\mathrm{Fv}$ values were statistically different due to the different $\mathrm{N}$ sources only in plants subjected to ECw of 2.5 and $3.5 \mathrm{dS} \mathrm{m}^{-1}$. For $\mathrm{ECw}$ of $2.5 \mathrm{dS} \mathrm{m}^{-1}$, highest $\mathrm{Fv}$ values (504.7 and 506.7 electrons quantum ${ }^{-1}$ ) were obtained in plants fertilized with calcium nitrate $(\mathrm{CN})$ and potassium nitrate $(\mathrm{KN})$, whereas, the highest $\mathrm{Fv}$ value (489 electrons quantum ${ }^{-1}$ ) in plants subjected to $\mathrm{ECw}$ of $3.5 \mathrm{dS} \mathrm{m}^{-1}$ was obtained under $\mathrm{KN}$ fertilization. 

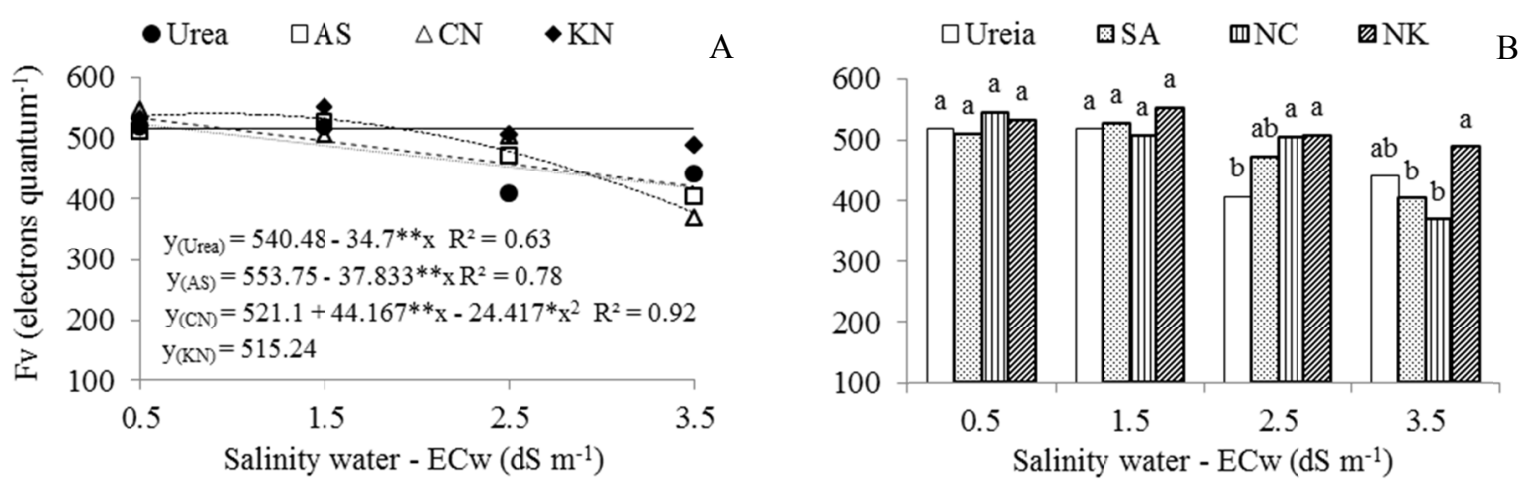

Figure 3. Follow-up analysis of levels of irrigation water salinity $(\mathrm{ECW})$ for each nitrogen source (urea, ammonium sulfate - AS, calcium nitrate $-\mathrm{CN}$ and potassium nitrate $-\mathrm{KN}$ ) (A) and follow-up analysis of nitrogen sources for each level of irrigation water salinity (B) for variable fluorescence $-\mathrm{Fv}$ of chlorophyll $a$ in soursop plants, 'Nordestina' variety, at 110 days after transplantation

Note. $* *, *=$ significant at 0.01 and 0.05 probability levels $(\mathrm{p} \leq 0.01$ and $\mathrm{p} \leq 0.01$ ). Averages not followed by same letter in salinity water level $(\mathrm{smd}=40.47)$ are different among them by Tukey's multiple range test at $5 \%$; smd $=$ significant minimum difference.

Reductions of Fv result in the loss of plants' capacity to transfer the energy of the ejected electrons from pigment molecules to the formation of the reducing agent NADPH, ATP and Fdr, consequently leading to lower $\mathrm{CO}_{2}$ assimilation capacity in the biochemical stage of photosynthesis (Rohácek, 2002; Baker, 2008). Reductions of this variable were observed in plants fertilized with ammoniacal sources (urea and AS), which may be associated with the increase of salt stress or increments in soil acidity promoted by these fertilizers. Tatagiba et al. (2014) and Silva et al. (2014) observed reductions in Fv values due to the increase of salinity in tomato and citrus, respectively.

Regarding the quantum yield of photosystem II ( Fv/Fm), the follow-up analysis of salinity levels for each $\mathrm{N}$ source (Figure 4A) demonstrated that plants fertilized with urea, AS and CN were negatively affected by the increment in irrigation water salinity, showing linear reductions of 1.66, 1.81 and 3.73\%, respectively, per unit increase in $\mathrm{ECw}$. However, $\mathrm{Fv} / \mathrm{Fm}$ was not affected by the increase of $\mathrm{ECw}$ in plants fertilized with $\mathrm{KN}$, which indicates the mitigating action of this $\mathrm{N}$ source on the salt-stress effects on this variable.
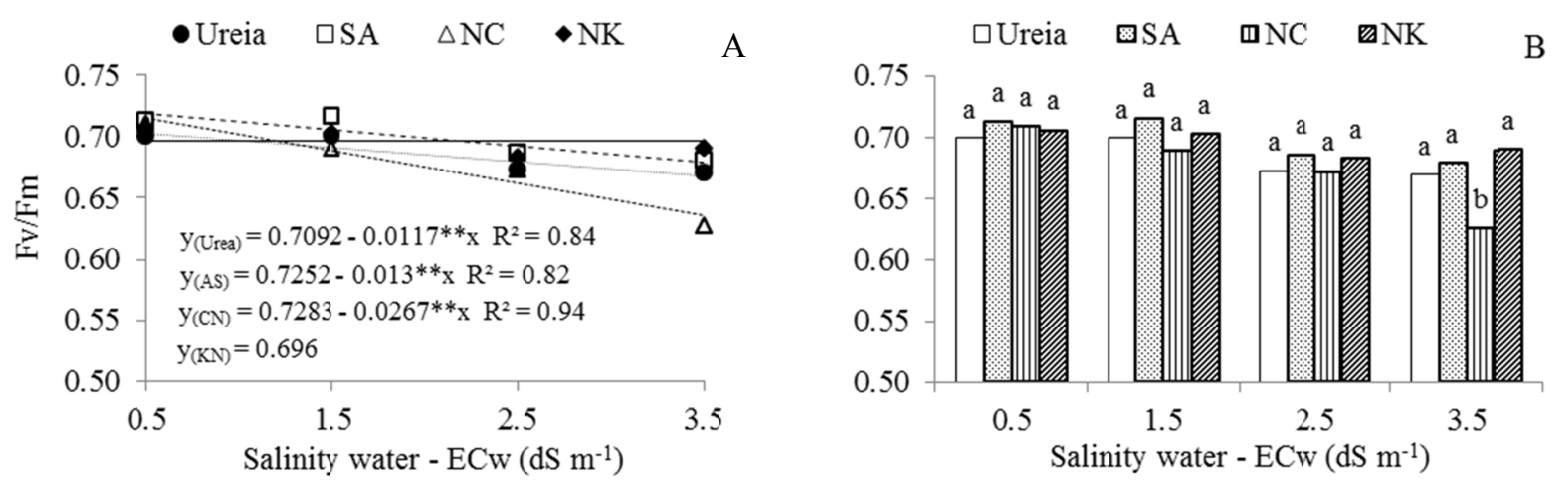

Figure 4. Follow-up analysis of levels of irrigation water salinity $(\mathrm{ECw})$ for each nitrogen source (urea, ammonium sulfate $-\mathrm{AS}$, calcium nitrate $-\mathrm{CN}$ and potassium nitrate $-\mathrm{KN})(\mathrm{A})$ and follow-up analysis of nitrogen sources for each level of irrigation water salinity $(\mathrm{ECw})(\mathrm{B})$ for the quantum efficiency of photosystem II $-\mathrm{Fv} / \mathrm{Fm}$ in soursop plants, 'Nordestina' variety, at 110 days after transplantation

Note. $* *, *=$ significant at 0.01 and 0.05 probability levels $(\mathrm{p} \leq 0.01$ and $\mathrm{p} \leq 0.01)$. Averages not followed by same letter in salinity water level $(\mathrm{smd}=0.0167)$ are different among them by Tukey's multiple range test at $5 \%$; smd $=$ significant minimum difference. 
According to the follow-up analysis of $\mathrm{N}$ sources for each level of water salinity (Figure 4B), the use of different $\mathrm{N}$ sources led to significant difference in the $\mathrm{Fv} / \mathrm{Fm}$ ratio only in plants irrigated with $3.5 \mathrm{dS} \mathrm{m}^{-1}$ water, and plants fertilized with calcium nitrate $(\mathrm{CN})$ exhibited lower value compared with the others.

In general, the other fluorescence parameters were also negatively affected by $\mathrm{CN}$ fertilization in plants irrigated $3.5 \mathrm{dS} \mathrm{m}^{-1}$ water, demonstrating that, at such salinity level, this fertilizer is inefficient in the reduction of salt stress and can intensify the deleterious effect caused by salinity.

The $\mathrm{Fv} / \mathrm{Fm}$ ratio is an estimate of the maximum quantum efficiency of the photochemical activity of photosystem II (PSII), when all reaction centers are open, and its decrease points to the large reduction of the first electron acceptor (pool of QA), which causes variation in the electron transport rate between photosystems I and II and, consequently, inhibition of photochemical activity (Baker; 2008), which may occur when plants are subjected to salt stress (Azevedo Neto et al., 2011; Tatagiba et al., 2014; Silva et al., 2014). Such inhibitory effect can be reduced with the utilization of potassium nitrate as $\mathrm{N}$ source, as observed in the present study.

Regarding the basal quantum yield of photosystem II (Fo/Fm), the follow-up analysis of salinity levels for each $\mathrm{N}$ source (Figure 5A) indicates that fertilization with urea, AS and $\mathrm{CN}$ led to respective increments of 6.40,4.62 and $9.37 \%$ per unit increase in $\mathrm{ECW}$. On the other hand, the use of $\mathrm{KN}$ did not cause significant difference in this variable in plants irrigated using solutions of different saline levels.

$\mathrm{Fo} / \mathrm{Fm}$ ratio indicates the basal quantum yield of the non-photochemical process in PSII and its implicit components are: minimum quantum yield in the dark-adapted state (DAS) and thermal dissipation quantum yield of PSII in DAS (Rohácek, 2002). According to this author, increment in this ratio is an indication of stress, as observed in the present study, in which this variable increased with the increment of salinity in plants fertilized with urea, AS and $\mathrm{CN}$. However, the stress was mitigated by the use of $\mathrm{KN}$, which did not cause variation in this variable with the increase of salinity.

In the follow-up analysis of $\mathrm{N}$ sources for each level of water salinity (Figure 5B), Fv/Fm ratio differed between the $\mathrm{N}$ sources only in plants irrigated using water with $\mathrm{ECW}$ of $3.5 \mathrm{dS} \mathrm{m}^{-1}$, and its lowest value, representing lower stress, occurred in plants fertilized with $\mathrm{KN}$.

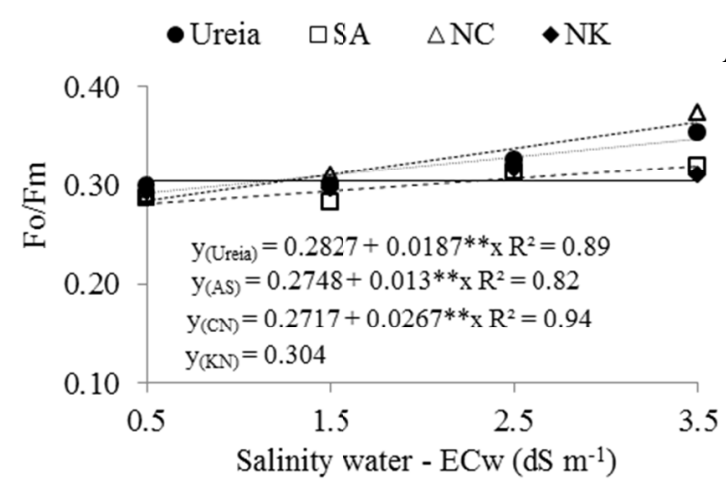

A

Figure 5. Follow-up analysis of levels of irrigation water salinity $(\mathrm{ECW})$ for each nitrogen source (urea, ammonium sulfate - AS, calcium nitrate $-\mathrm{CN}$ and potassium nitrate $-\mathrm{KN})(\mathrm{A})$ and follow-up analysis of nitrogen sources for each level of irrigation water salinity (B) for the basal quantum yield of photosystem II -

Fo/Fm of chlorophyll $a$ in soursop plants, 'Nordestina' variety, at 110 days after transplantation

Note. $* *, *=$ significant at 0.01 and 0.05 probability levels $(\mathrm{p} \leq 0.01$ and $\mathrm{p} \leq 0.01)$. Averages not followed by same letter in salinity water level $(\mathrm{smd}=0.0168)$ are different among them by Tukey's multiple range test at $5 \%$; smd $=$ significant minimum difference.

In general, chlorophyll a variables in the present study did not vary with the increment in irrigation water salinity under $\mathrm{KN}$ fertilization, demonstrating that this fertilizer mitigated the effect of salt stress on photochemical efficiency and that such reduction was more effective in plants irrigated using water of higher salinity, $\mathrm{ECw}=$ $3.5 \mathrm{dS} \mathrm{m}^{-1}$. These results suggest that the supply of $\mathrm{NO}_{3}{ }^{-}$and $\mathrm{K}^{+}$by this fertilizer, under saline conditions, can increase $\mathrm{N}$ and $\mathrm{K}$ contents in the leaves, compared with $\mathrm{Cl}^{-}$and $\mathrm{Na}^{+}$contents, thus minimizing the osmotic and toxic effects of these ions and reestablishing nutritional balance (Blanco et al., 2008). 
Nitrogen and potassium are essential nutrients in the photochemical reactions of photosynthesis (Taiz \& Zeiger, 2013) and may have great influence on soursop, because they are the most absorbed in its initial growth stage (São José et al., 2014). Nitrogen is present in chlorophyll molecules, responsible for the capture and transfer of energy to the reaction centers, and also composes the protein complexes that act on the transport of electrons in the thylakoid membrane, such as the cytochrome b6f complex and plastocyanin, which acts in the electron transfer between PSII and PSI, and the enzymes Fd and FNR, which use the ejected electrons to form the reducing agent NADPH used in the carboxylation reactions (Taiz \& Zeiger, 2013). Potassium becomes essential in the catalysis of the enzymes involved in electron transfer (9Fd and FNR), because it acts as enzyme activator (São José et al., 2014).

\section{Conclusions}

Irrigation water salinity from $0.5 \mathrm{dS} \mathrm{m}^{-1}$ decreases the contents of photosynthetic pigments and photochemical efficiency in soursop plants, 'Nordestina' variety, at 110 days after transplantation.

Fertilization with different $\mathrm{N}$ sources does not cause alterations in the contents of photosynthetic pigments, but the use of potassium nitrate mitigates the salt-stress effect on photochemical efficiency, particularly evidenced at water salinity of $3.5 \mathrm{dS} \mathrm{m}^{-1}$.

\section{References}

Andrade Júnior, W. P., Pereira, F. H. F., Fernandes, O. B., Queiroga, R. C. F., \& Queiroga, F. M. (2011). Efeito do nitrato de potássio na redução do estresse salino no meloeiro. Revista Caatinga, 24(3), 110-119. Retrieved from https://periodicos.ufersa.edu.br/index.php/caatinga/article/view/2280/4762

Azevedo Neto, A. D., Pereira, P. P. A., Costa, D. P., \& Santos, A. C. C. (2011). Fluorescência da clorofila como uma ferramenta possível para seleção de tolerância à salinidade em girassol. Revista Ciência Agronômica, 42(4), 893-897. https://doi.org/10.1590/S1806-66902011000400010

Baker, N. R. (2008). Chlorophyll fluorescence: A probe of photosynthesis in vivo. Annual Review of Plant Biology, 59, 89-113. https://doi.org/10.1146/annurev.arplant.59.032607.092759

Bernardo, S., Soares, A. A., \& Mantovani, E. C. (2006). Manual de irrigação (8th ed., p. 625). Viçosa: UFV.

Binotti, F. F. S., ARF, O., Cardoso, E. D., Sá, M. E., Buzetti, S., \& Nascimento, V. (2010). Fontes e doses de nitrogênio em cobertura no feijoeiro de inverno irrigado no sistema plantio direto. Bioscience Journal, 26(5), 770-778. Retrieved from http://www.seer.ufu.br/index.php/biosciencejournal/article/view/7189/5267

Blanco, F. F., Folegatti, M. V., \& Henriques Neto, D. (2008). Doses de N e K no tomateiro sob estresse salino: I. Concentração de nutrientes no solo e na planta. Revista Brasileira de Engenharia Agrícola e Ambiental, 12(1), 26-33. https://doi.org/10.1590/S1415-43662008000100004

Borges, A. L., \& Silva, D. J. (2011). Fertilizantes para fertirrigação. In V. F. Sousa, W. A. Marouelli, E. F. Coelho, J. M. P. Maurício, \& A. Coelho Filho (Eds.), Irrigação e fertirrigação em fruteiras e hortaliças (pp. 253-264). Brasília: Embrapa Informação Tecnológica.

Cavalcante, L. F., Dias, T. J., Nascimento, R., \& Freire, J. L. O. (2011). Clorofila e carotenoides em maracujazeiro-amarelo irrigado com águas salinas no solo com biofertilizante bovino. Revista Brasileira de Fruticultura, 33(Spel.), 699-705. https://doi.org/10.1590/S0100-29452011000500098

Cavalcanti Junior, A. T., Correia, D., Okumura, H. H., \& Alves, J. T. (2010). Formação de mudas enxertadas de gravioleira em substratos com fertilizantes minerais e orgânicos (p. 24). Fortaleza: Embrapa Agroindústria Tropical. Retrieved from https://ainfo.cnptia.embrapa.br/digital/bitstream/item/33735/1/BP10004.pdf

Claessen, M. E. C. (1997). Manual de métodos de análise de solo (2nd ed., p. 212). Rio de Janeiro, RJ: Embrapa-CNPS.

Coelho, M. A., \& Soncin, N. B (1982). Geografia do Brasil (p. 368). São Paulo, SP: Moderna.

Falk, J., \& Munné-Bosch, S. (2010). Tocochromanol functíons in plants: Antioxidation and beyond. Journal of Experimental Botany, 61(6), 1549-1566. https://doi.org/10.1093/jxb/erq030

Fernandes, O. B., Pereira, F. H. F., Andrade Júnior, W. P., Queiroga, R. C. F., \& Queiroga, F. M. (2010). Efeito do nitrato de cálcio na redução do estresse salino no meloeiro. Revista Caatinga, 23(3), 93-103. Retrieved from https://periodicos.ufersa.edu.br/index.php/caatinga/article/view/1766/4597

Ferreira, D. F. (2011). Sisvar: Um sistema computacional de análise estatística. Ciência e agrotecnologia, 35(6), 1039-1042. https://doi.org/10.1590/S1413-70542011000600001 
Freire, J. L. O., Cavalcante, L. F., Nascimento, R., \& Rebequi, A. M. (2013). Teores de clorofila e composição mineral foliar do maracujazeiro irrigado com águas salinas e biofertilizante. Revista Ciências Agrárias, 36(1), 57-70. Retrieved from http://www.scielo.mec.pt/pdf/rca/v36n1/v36n1a09.pdf

INMET (Instituto Nacional de Meteorologia). (2017). Normais climatológicas do Brasil 1961-1990. Retrieved October 20, 2017, from http://www.inmet.gov.br/portal/index.php?r=clima/normaisClimatologicas

Lichtenthäler, H. K. (1987). Chlorophylls and carotenoids: Pigments of photosynthetic biomembranes. In L. Packer \& R. Douce (Eds.), Methods in enzymology (Vol. 148, pp. 350-381). London, England: Academic Press. https://doi.org/10.1016/0076-6879(87)48036-1

Munns, R., \& Tester, M. (2008). Mechanisms of salinity tolerance. Annual Review of Plant Biology, 59, 651-681. https://doi.org/10.1146/annurev.arplant.59.032607.092911

Novais, R. F., Neves J. C. L., \& Barros, N. F. (1991). Ensaio em ambiente controlado. In A. J. Oliveira (Ed.), Métodos de pesquisa em fertilidade do solo (pp. 189-253). Brasília: Embrapa-SEA.

Oliveira, F. A., Oliveira, F. R. A., Campos, M. S., Oliveira, M. K. T., Medeiros, J. F., \& Silva, O. M. P. (2010). Interação entre salinidade e fontes de nitrogênio no desenvolvimento inicial da cultura do girassol. Revista Brasileira de Ciências Agrárias, 5(4), 479-484. https://doi.org/10.5039/agraria.v5i4a806

Rohácek, K. (2002). Chlorophyll fluorescence parameters: The definitions, photosynthetic meaning, and mutual relationships. Photosynthetica, 40(1), 13-29. https://doi.org/10.1023/A:1020125719386

Rozane, D. E., \& Natale, W. (2014). Calagem, adubação e nutrição mineral de anonáceas. Revista Brasileira de Fruticultura, 36(Spel.), 166-175. https://doi.org/10.1590/S0100-29452014000500020

Sacramento, B. L., Cruz, T. S., Silva, L. L., Mota, K. N. A. B., \& Azevedo Neto, A. D. (2014). Pigmentos e teores de solutos orgânicos em plantas de aguapé sob estresse salino. Enciclopédia Biosfera, 10(18), 3344-3354. Retrieved from http://www.conhecer.org.br/enciclop/2014a/CIENCIAS\%20BIOLOGICAS/ pigmentos.pdf

São José, A. R., Prado, N. B., Bomfim, M. P., Rebouças, T. N. H., \& Mendes, H. T. A. (2014). Marcha de absorção de nutrientes em anonáceas. Revista Brasileira de Fruticultura, 36(Spel.), 176-183. https://doi.org/10.1590/S0100-29452014000500021

Silva, L. A., Brito, M. E. B., Sá, F. V. S., Moreira, R. C. L., Soares Filho, W. S., \& Fernandes, P. D. (2014). Mecanismos fisiológicos em híbridos de citros sob estresse salino em cultivo hidropônico. Revista Brasileira de Engenharia Agrícola e Ambiental, 18(Supl.), S1-S7. https://doi.org/10.1590/1807-1929/ agriambi.v18nsupps1-s7

Taiz, L., \& Zeiger, E. (2013). Fisiologia vegetal (5th ed., p. 954). Porto Alegre: Artmed.

Tatagiba, S. D., Moraes, G. A. B. K., Nascimento, K. J. T., \& Peloso, A. F. (2014). Limitações fotossintéticas em folhas de plantas de tomateiro submetidas a crescentes concentrações salinas. Engenharia na Agricultura, 22(2), 138-149. https://doi.org/10.13083/1414-3984.v22n02a05

Távora, F. J. A. F., Lima, E. C. C., \& Hernandez, F. F. F. (2004). Composição mineral das raízes, caules e folhas em plantas jovens de graviola submetidas a estresse salino. Revista Ciência Agronômica, 35(1), 44-51. Retrieved from http://www.ccarevista.ufc.br/site/down.php?arq=05rca35-1.pdf

\section{Copyrights}

Copyright for this article is retained by the author(s), with first publication rights granted to the journal.

This is an open-access article distributed under the terms and conditions of the Creative Commons Attribution license (http://creativecommons.org/licenses/by/4.0/). 